\title{
"China English" and ELT in China: Global Vision and Local Spirit
}

\author{
Haiyang Jiang \\ School of Foreign Languages and Literatures, Chongqing Normal University, Chongqing, China
}

\begin{abstract}
China English" is an objective reality, which is an English variety in China. It is different from other varieties such as "Cantonese English", "Chinese Pidgin English", "Chinglish". In China, "China English" needs to be integrated into ELT, which not only helps to make up for the gap in the cultural exchange between China and the West, but also is conducive to the spread of Chinese culture. It is the best English carrier for Chinese culture. Although "China English" is not yet a national variety of English, its importance is self-evident. Meanwhile, it also brings some enlightenment to ELT in China.
\end{abstract}

Index Terms-"China English", English teaching, intercultural communication

\section{INTRODUCTION}

With the continuous advancement of the times, the relationship among countries is getting closer and closer. At the same time, English has been spread to all parts of the world and it becomes a worldwide language. English has experienced a transitional period, from native language to second language and to foreign language, and finally becomes a lingua franca. B.B.Kachru (1992), a well-known American sociolinguist and professor at the University of Illinois, proposed three concentric circles to view the current sociolinguistic profile of English: Inner Circle (ie, native language circle, such as UK, Australia etc.), Outer Circle (such as India, Jamaica, etc., which has been widely used as an institutionalized language in the local area) and Expanding Circle (ie, English as a foreign language, such as German, Japan, etc.). We can see that the fact that the population of expansion circle is larger than that of the outer circle and the population of outer circle is larger than that of inner circle. As English becomes more and more globalization, localized English is also producing. At the beginning, there was only one English variety in the world, that is British English. Many people regard it as "King English" or "Standard English". With the completion of industrial revolution and colonial expansion, American English has quietly emerged. Therefore, many people always ask me that "do you think which one is more standard, British English or American English?" Actually, most people are still inclined to choose British English, especially its pronunciation. But as the international status of the United States continues to increase, there are more followers of American English. Later, British English and American English are equal and both become the mainstream of English teaching content. However, in addition to these two Englishes, there are many English varieties in the world nowadays. Such as Australian English, Singapore English, Sri Lankan English, Canadian English, Irish English, New Zealand English, South African English, etc. Some people even divide Australian English into Western Australian English and North Australian English. The status of British English and American English has been hit hard. "English" is an uncountable noun, but now there are "World Englishes", "New Englishes" and other expressions. There are also some journals named after "Englishes", such as World Englishes, Asian Englishes, which also reflects the globalization and localization of English. Some English varieties have been integrated into local English teaching, which has brought unprecedented crisis to the so-called "Standard English". In China, the localization of English is also inevitable. Now English has become a language that modern Chinese people are willing to use in their daily lives. Twenty-eight years ago, scholars put forward the term "China English", and its existence also caused great controversy. In the context of English globalization, discussing and studying "China English" will have some inspiration for ELT in China.

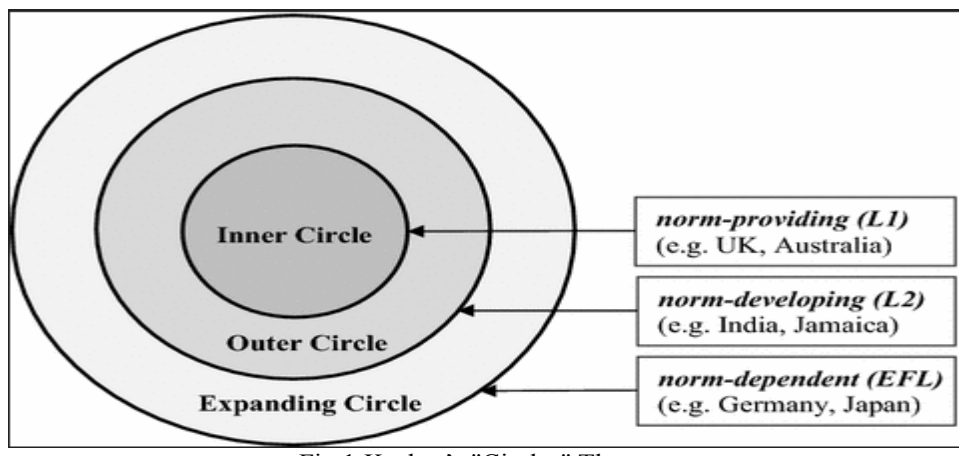

Fig.1 Kachru's "Circles" Theory 


\section{NATIVALiZATION OF ENGLish IN CHINA}

English has a long history of development in China. It has been introduced to China since the Qing Dynasty, and it is now a compulsory course for primary and secondary schools. When British sent people to Guangzhou for the first time in 1617, it marked the beginning of English entry into China. Since the 17th century, English has been spread and used in this land for nearly five centuries. In fact, there are many English varieties in China, each of them has different characteristics in different historical stages, and everyone also has its special name. For example, "Cantonese English", "Chinese Pidgin English", "Chinglish" (is also called "Chinese English") and "China English".

\section{A. "Cantonese English"}

In China, the earliest English variety can be traced back to the Qing Dynasty. "Cantonese English" is seen as the beginning of the localization of English in China. It originated from the so-called "Macanese". In the 16th century, Portugal began to occupy Macao in the name of renting. When doing business with local people, it is necessary to have a common language to communicate, so "Macanese" appeared. As the international status of British continues to increase, "Cantonese English" has replaced "Macanese" gradually.

Although it is not a formal language, it has an irreplaceable role in the period of its existence, solving the problem of being unable to communicate at that time because there was no common language. With the outbreak of the "First Opium War", the signing of the "Nanjing Treaty", the opening of the trading port, the economic center had been transferred from Guangzhou to Shanghai, and "Cantonese English" has slowly withdrawn from the historical stage.

\section{B. "Chinese Pidgin English"}

However, there was another English variety emerging in Shanghai, which may be the most familiar English variety for us. At that time, the Chinese were not able to speak English, and foreigners also could not speak Chinese. The two sides needed a language to communicate urgently, and then a "mixed English-Chinese language" was produced, that is "Chinese Pidgin English". It is a member of "Pidgin Family". Holm (1988) defines a pidgin as:

A reduced language that results from extended contact between groups of people with no language in common; it evolves when they need some means of verbal communication, perhaps for trade, but no group learns the native language of any other group for social reasons that may include lack of trust or of close contact.

Wardhaugh (2000) thinks it is a language with no native speakers; it is no one's first language but is a contact language.

Therefore, we can see that the emergence of these English varieties is due to the fact that neither side of the communication has a common language.

Although the form of "Chinese Pidgin English" is the same as English, it is quite different. Such as voice, vocabulary, grammar, etc. The following doggerel is very popular at that time:

$$
\begin{aligned}
& \text { 系 }
\end{aligned}
$$

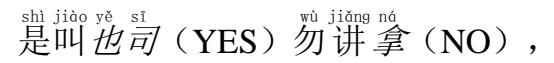

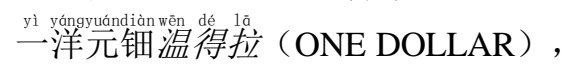

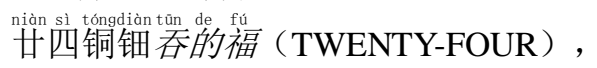

$$
\begin{aligned}
& \text { 趐梯䢍趐梯喝杯茶（HAVE TEA）, }
\end{aligned}
$$

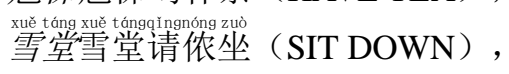

$$
\begin{aligned}
& \text { 红头阿穾等泼度 (KEEP DOOR), } \\
& \text { 自家芜兄弟勃拉茶（BROTHER）, } \\
& \text { 爷叫发率娘卖率 (FATHER / MOTHER), } \\
& \text { 丈人阿爸发音落 (FATHER IN LAW)。 }
\end{aligned}
$$

"Chinese Pidgin English" is the same as "Cantonese English", it is not a formal language, but it is of great significance to the social development and foreign trade at that time. As time went by, China is getting stronger and stronger, and this language slowly withdraws from the historical stage because it did not have an environment for survival.

\section{C. "Chinglish" ("Chinese English")}

With the victory of the War of Resistance Against Japanese Aggression and the establishment of the People's Republic of China, China slowly began to pay attention to the study of foreign languages. At the beginning, due to the close relationship between China and Soviet Union, Russian is the main foreign language in China. However, with the deterioration of Sino-Russian relation and the establishment of diplomatic relation between China and the Commonwealth countries, English has become China's first foreign language. In this context, "Cantonese English" and "Chinese Pidgin English" have no environment to survive, but there is a new localized English-"Chinglish". It is also called "Chinese English" or "Sinicized English". "Good Good Study and Day Day Up" (study hard and make progress 
every day) and "Long Time No See" are the most representative "Chinglish". Li (1993) believes that "Chinglish" is an abnormal English that does not conform to English culture. Pinkham (2000) defines it is that misshapen, hybrid language that is neither English nor Chinese but that might be described as "English with Chinese characteristics".

The main reason for this variety is the interference of the mother tongue. When learning English, many Chinese have developed Chinese thinking. In the process of learning English, it is inevitable to use the rules of the native language to apply the English grammar. This is what we call "negative transfer." When the native language and the target language have the same characteristic, if the learner uses some rules of the mother tongue as an auxiliary tool, it must appear the "negative transfer" phenomenon (Zhang, 1995). A very typical feature of "Chinglish" is to translate words one by one. For example:

\begin{tabular}{|c|c|c|}
\hline Chinese & Chinglish & English \\
\hline 花心 (hua xin) & flower heart & fickle in love \\
\hline 红糖 (hong tang) & red sugar & brown sugar \\
\hline 河马 (he ma) & river horse & hippopotamus \\
\hline 红茶 (hong cha) & red tea & black tea \\
\hline 大雨 $($ da yu) & big rain & heavy rain \\
\hline
\end{tabular}

\section{D. "China English"}

However, "China English" is different from the English varieties above. In China, it is Ge Chuangui who first puts forward the term "China English." Ge (1980) thinks that "Four Books" (四书), "Five Classics" (五经), "four modernizations" (四个现代化) and "xiucai" (秀才) are not "Chinglish" but "China English". After more than 20 years of discussion and analysis, the term "China English" has caught a lot of attention. At first, it was conflated with "Chinglish" or "Chinese English". With the research and analysis of some scholars, many people could distinguish these terms.

So what is "China English"? Rong (1991) defines "it is English that is used used by Chinese people in China and is based on the standard English with Chinese characteristics." In fact, this definition is not very rigorous, but there is one point that is worthy of recognition, that is "based on the standard English". Modiano (1993) said that the English varieties that can be used in the world must have a core. This core is also the fundamental starting point for English as an international language. If the variety leaves this core, then it is unacceptable. Just like the varieties we talked about above. Although they are they are the localization of English in China, they are not based on the standard English. Therefore, these English is malformed and mixed, and they are not accepted by most people. Ji (2002) believes that the reason for the emergence of "China English" is mainly due to cultural vacancies in cultural exchanges between English and Chinese. There are always some words in Chinese that are not in English. For example, the "Four Books" and "Five Classics" mentioned above are all unique Chinese vocabulary, expressing culture and things with Chinese characteristics. When we introduce foreigners to Chinese characteristic culture or unique things, we need "China English." Without "China English," we can't communicate each other.

Since "China English" is an objective reality, it has the value and significance of its existence. Firstly, it is conducive to exchanges between China and the West. As mentioned above, the emergence of "China English" makes up for the gap between Chinese and Western cultures, which is conducive to the exchanges between China and the West. Secondly, it is conducive to the spread of Chinese culture. Although there have been already many Chinese loanwords in English, China's current international status is getting higher and higher, and those loan words are from a done deal. Thirdly, it enriches the content of English. The emergence of "China English" not only expands the English vocabulary, but also enriches its expression. Especially in terms of vocabulary, there are many words that were not available before. Last but not least, it is conducive to the translator's translation. When the translator encounters a sentence with Chinese characteristics, if there is no "China English", then he may not be able to translate correctly.

\section{Global Vision: Stones From Other Hills May SerVe to Polish Jade}

Does localized English integrate into English teaching in other countries and regions? The case is self-evidence. For example, the famous Indian poet Tagore's works, who won the Nobel Prize in Literature, have a lot of "Indian English" in his works. Monfared (2018) conducted a survey of 260 English teachers from India and Iran and used questionnaires to ask these teachers what do they think about English variety. It turns out that Indians are very fond of "Indian English" (that is the localization of English in India), attach great importance to local English, and often use this English variety in their daily life and English teaching. The degree of "Indian English" accepted by Indians is still quite high. This shows that Indians need to use this localized English to communicate and write, which has become an indispensable communication tool in their lives.

"Singapore English" has long been a common language in the local area and it is used as a symbol of Singapore identity. At the beginning, the Singapore government still rejected the existence of this localized English. They believed 
that this English variety is not conducive to people's communication. In 2000, the Singapore government launched a campaign that named "Speak Good English Movement" (SGEM). The aim of this campaign is to ensure that Singaporeans recognize the importance of standard English and promote its use. However, in the past few decades, almost every Singaporean used "Singapore English". In this context, this movement still failed to make "Singapore English" disappear from the land of Singapore. As the relationship between Singapore and other countries are getting more and more close, the use of this English variety has become more widespread. What's more, more and more people are familiar with this variety. "Singapore English" is a product of social necessity, and its appearance is not accidental. Actually, This localized English will not only undermine the ability of Singaporeans to learn "standard English", but will also help them better communicate with the outside world.

\section{LocAl SpIRIT: The NeCESSITy OF INTERGRATING "ChINA ENGLISH" INTO ELT IN CHINA}

From the above we can see that many English varieties have been accepted and are still widely used. "China English" should also be like this, because it can not only express the unique culture and things of China, but also inject a new blood into the world of English. Everyone should have encountered this situation. When you want to express some Chinese unique things in English, you are not able to find some suitable words or phrases. Or if you meet a foreign teacher or a foreign friend and ask you what you have eaten for breakfast, you know what you ate, but you can't express it in English. Until now, there are some English textbooks in which the English of "jiaozi" (饺子) is still used as "dumpling", but the true meaning of this word does not refer to Chinese dumpling, it means "a round lamp pf flour and fat mixed with water, cooked in boiling liquid and served with meat". This kind of thing is too much in China, such as "tangyuan" (汤圆), "chaoshou" (抄手),"yuntun" (云吞) and so on. Some people also suggested using "ravioli" to refer to "dumpling", but it is Italian dumpling, not Chinese dumpling. After serious consideration, we should use the Chinese pinyin of dumpling to refer to "dumpling", that is "jiaozi". When communicating with foreigners, you can't deliberately use the words that similar on the surface in order to let the other person understand what you are talking about. This may cause misunderstanding. Therefore, we must use "China English" to communicate, although foreign friends may not understand it at that time, but after explanation, they can konw what we want to express.

Originally, Chinese people studied English in order to communicate with foreigners. This is also the inevitable result of the establishment of diplomatic relations between China and foreign countries. In the early days of reform and opening up, China began to develop slowly, and its comprehensive strength was relatively weak. Therefore, many things were imported from abroad. But it is different now. China has become the world's largest developing country and the world's second largest economy. Under such circumstances, China has exported many things. On the one hand, we must learn some advanced science and technology from abroad. On the other hand we should spread the profound Chinese culture to abroad. To spread Chinese culture successfully, "China English" is essential. However, the term "China English" is not very popular in China. Many people will still confuse this term with "Chinglish". From this we can see that everyone's understanding of "China English" is not deep enough. Therefore, when expressing Chinese unique culture and things in English, some of them will become dumb, and they don't know how to say it in English.

In China, the people we communicate in English are often not English native speakers. Compared with people in the United States and Europe, the foreign friends we often encounter are from neighboring countries. Such as Japan, the South Korea, Thailand and so on. And many of the things we talk about are Chinese things and stories. Therefore, the importance of "China English" is self-evident. When people communicate with others, the main consideration is the realization of the purpose of communication. Intercultural communication is a kind of mutual communication, and it is not just that one party transmits content to the other party. It includes both inward introduction and external output.

The introduction of "China English" has brought new research topics to our English teaching, and also lies in the choice of teaching content. Learning a language really requires understanding the culture behind the language, but it is not conducive for language learning to blindly understand the culture of a country unilaterally. It is like saying that a person only learns English every day, does not learn his native language, and finally the knowledge he wants to learn does not learned well, and the knowledge he has mastered has forgotten. There is a saying that is quite reasonable, "your native language determines your foreign language." In China, many English teachers often let students learn about Western culture in the process of teaching English, which is good for them to master the language. Although this approach has certain effects, it must adhere to the principle of appropriateness. Throughout the current many English textbooks, many of the texts are about Western culture, politics, and so on, and there are very few topics about China. For this trend, we should take some measures. In fact, Chinese English textbooks have also gone through some detours in history. Sometimes, they are all about China. Sometimes, they are all about the West. For both, we should adopt a balanced approach, which will help to develop students' intercultural communication skills. In our English textbooks, we should add some topics about China. Most students are familiar with Chinese culture and things. Talking about China in English can not only stimulate students' interest, but also make them feel a sense of pride. For the language materials with Chinese cultural characteristics, we can not only choose the passage written by Westerners, but also written by Chinese people, the premise is that there is no "Chinglish". When we are learning English, teachers always say that we should read articles written by Westerners, because these Englishes are authentic; we should not read articles written by Chinese people in English, because many articles are not idiomatic. This view seems to be correct on the surface, but it is not. English is no longer the language of the British and America, but the language of the world. In 
fact, this view is also one-sided. Just reading articles written by foreigners will only make you more and more out of the cultural circle in which you are. Therefore, it is necessary to select some articles written by Chinese people in English textbooks. Peng (2017), president of Beijing Foreign Studies University, also believes that foreign language education in China should be further developed Chinization and localization. He pointed out that from the perspective of foreign language education in various countries around the world, successful foreign language education does not have a fixed pattern that must be followed, but only combined with the actual situation of the country and highlight the regional cultural colour.

\section{CONCLUSION}

In summary, "China English" is not only an objective reality but also has practical significance. Although "China English" is not yet a national variety of English, it has shown an unstoppable trend. I believe that in the near future, it will be integrated into the world of English as an indispensable part of the world of English, and will eventually be accepted by the world as an independent and powerful national variety of English. There is no such thing as "Standard English" in this world. English no longer belongs to which country, but to the world. At the same time, we should retain our Chinese identity in ELT. So what should we do specifically? Firstly, we must work out a new English syllabus, which is to solve problems from the source. With a proper syllabus, correct teaching activities can be carried out. Secondly, we must pay attention to the compilation of teaching materials. The teaching materials should not only include topics about Western culture, but be added to some Chinese elements appropriately. Articles written by Chinese people also need to be considered. Thirdly, we need to train some teachers with a world English view. A teacher is a light to a student, he can guide him to the right path of learning. Finally, in the English test, many Chinese elements should also be added. "To learn, to use" is very important.

\section{REFERENCES}

[1] Ge Chuangui. (1980). A Talk on Chinese-English Translation. Chinese Translators Journal, 2, 1-8.

[2] Holm, J. (1988). Pidgins and Creoles. 2 vols. Cambridge: Cambridge University Press.

[3] Ji Yushan \& Zhu Wenxia. (2002). English Variety and Chinese Culture. Beijing: People's Public Security University of China Press.

[4] Kachru, B. B. (1992). Teaching World Englishes. In Kachru, B. B (Eds.), The Other Tongue: English across Cultures (2nd ed.). Urbana and Chicago: University of Illinoid Press, 355-365.

[5] Li Wenzhong. (1993). China English and Chinese English. Foreign Language Teaching and Research, 4, 18-24.

[6] Modiano, M. (1999). Standard English (es) and Educational Practices for the Worlld's Lingua Franca. English Today, 4, 3-13.

[7] Monfared, A. (2018). English or Englishes? Outer and Expanding Circle Teachers' Awareness of and Attitudes towards their Own Variants of English in ESL/EFL Teaching Contexts. Australian Journal of Teacher Education, 2, 56-75.

[8] Peng Long. (2017).The Important Trend of the Development of Foreign Language Education in China. China Higher Education, 7, 16-19.

[9] Pinkham, J. (2000). The Translator's Guide to Chinglish. Beijing: Foreign Language Teaching and Research Press.

[10] Rong Pei. (1991). China English is an objective reality. Journal of PLA University of Foreign Languages, 1, 1-8.

[11] Wardhaugh, R. (2000). An Introduction to Sociolinguistics. Beijing: Foreign Language Teaching and Research Press.

[12] Zhang Guoyang \& Zhu Yafu. (1995). Foreign Language Educational Linguistic. Nanning: Guangxi Education Press.

Haiyang Jiang was born in Chong Qing, China in 1993. Now, he is a postgraduate student from Chongqing Normal University majored in Foreign Linguistics and Applied Linguistics. His research interests include foreign language teaching and sociolinguistics.

Published paper: A New Study of China English and Chinese English (Journal of Qiqihar Junior Teachers' College). 